\title{
EDUKASI: PENINGKATAN PENGETAHUAN MASYARAKAT TENTANG VAKSINASI COVID-19 DI DUSUN TEMPIT DESA BAJUR LOMBOK BARAT
}

\author{
Ernawati $^{1 *}$, Baik Heni Rispawati ${ }^{2}$, Dewi Nursukma Purqoty ${ }^{3}$, Fitri \\ Romadonika ${ }^{4}$, Raudatul Jannah ${ }^{5}$ \\ ${ }^{1-5}$ STIKES Yarsi Mataram
}

E-mail Korespondensi: ernawati091984@gmail.com

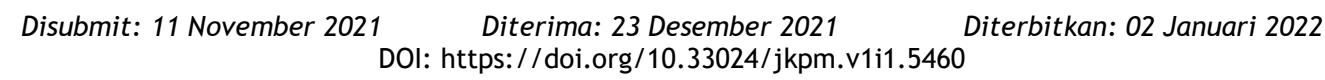

\begin{abstract}
ABSTRAK
Vaksin Covid-19 merupakan bentuk pencegahan yang berfungsi mendorong pembentukan kekebalan tubuh sfesifik pada penyakit covid 19 agar terhindar dari tertular atau memungkinkan sakit berat. Sekitar 7,6 persen masyarakat yang menolak untuk divaksinasi dan 26,6 persen masyarakat belum memutuskan dan masih kebingungan untuk melakukan vaksinasi, sehingga diperlukan adanya edukasi kesehatan tentang vaksin Covid-19. Tujuan setelah dilakukan pendidikan kesehatan, diharapkan dapat meningkatkan pengetahuan dan pemahaman masyarakat tentang penyakit Covid-19, cara pencegahannya dan pemahaman tentang program vaksinasi Covid-19 di dusun tempit desa bajur lombok barat.. Adapun kegiatan yang dilakukan berupa kegiatan edukasi menggunakan LCD untuk penyampaian materi dan peserta diberikan leaflet. Terdapat peningkatan pengetahuan dan pemahaman masyarakat tentang program vaksinasi covid-19 dari $60 \%$ menjadi $90 \%$.
\end{abstract}

Kata Kunci: Covid-19, Vaksinasi, Penyuluhan

\begin{abstract}
The Covid-19 vaccine is a form of prevention that functions to encourage the formation of specific immunity for COVID-19 disease to avoid contracting or allowing serious illness. Around 7.6 percent of the people refuse to be vaccinated and 26.6 percent of the people have not decided and are still confused about getting vaccinated, so health education about the Covid-19 vaccine is needed. The goal after health education is carried out is that it is expected to increase public knowledge and understanding of the Covid-19 disease, how to prevent it and understanding of the Covid-19 vaccination program in the tempit hamlet, Bajur Village, West Lombok. The activities carried out are in the form of educational activities using LCD to deliver material and participants were given leaflets. There is an increase in public knowledge and understanding of the covid-19 vaccination program from $60 \%$ to $90 \%$.
\end{abstract}

Keywords: Covid-19, vaccination, Counseling 


\section{PENDAHULUAN}

Pada akhir Desember 2019 diawali dengan adanya kasus pneumonia yang tidak diketahui etiologinya di Wuhan, China. Berdasarkan hasil data epidemiologi, kasus tersebut diduga berhubungan dengan Pasar Seafood di Wuhan. Kemudian pada tanggal 7 Januari 2020, pemerintah China kemudian mengumumkan bahwa penyebab kasus tersebut adalah Coronavirus jenis baru yang kemudian diberi nama SARS-CoV-2 (Severe Acute Respiratory Syndrome Coronavirus 2). Virus ini berasal dari famili yang sama dengan virus penyebab SARS dan MERS. Meskipun berasal dari famili yang sama, namun SARS-CoV-2 lebih menular daripada SARS-CoV dan MERS-CoV. Tata laksana virus COVID-19 mendapatkan rekomendasi dari WHO untuk tindakan pencegahan penyebaran COVID-19 antara lain adalah melakukan hand hygiene, social distancing, memakai masker, dan meningkatkan daya tahan tubuh dan vaksinasi. Banyak hal yang dapat dilakukan untuk meningkatkan daya tahan tubuh, salah satunya yaitu mengkonsumsi makanan yang bergizi, olah raga, menghindari stress, dan mengkonsumsi suplemen kesehatan. (Izazi dan Kusuma 2020).

Vaksin adalah salah satu cara yang paling efektif dan ekonomis untuk mencegah penyakit menular. Sehingga diperlukan untuk membuat pengembangan vaksin agar lebih efektif untuk melemahkan infeksi virus corona. Sejauh ini lebih dari 40 perusahaan farmasi dan lembaga akademis di seluruh dunia telah meluncurkan program pengembangan vaksin mereka untuk melawan virus COVID-19. (Makmun dan Hazhiyah 2020)

Vaksinasi adalah pemberian vaksin (antigen) yang dapat merangsang pembentukan imunitas (anty body) sistem imun didalam tubuh. Vaksinasi sebagai upaya pencegahan primer yang sangat handal mencegah penyakit yang dapat dicegah dengan vaksinasi.dengan prosedur vaksinasi yang benar di harapkan akan diperoleh kekebalan yang optimal, penyuntikan yang aman dan kejadian ikutan pasca imunisasi (KIPI) yang minimal.

Vaksin Covid 19 bukanlah obat, vaksin diberikan pada orang yang sehat untuk mencegah penyakit tertentu yang menjangkit orang tersebut. Vaksin Covid 19 merupakan bentuk pencegahan yang berfungsi mendorong pembentukan kekebalan tubuh sfesifik pada penyakit Covid 19 agar terhindar dari tertular atau memungkinkan sakit berat. Vaksinasi Covid-19 dilakukan setelah kepastian keamanan dan keampuhannya ada, merupakan upaya untuk menurunkan kesakitan dan kematian dan mendorong terbentuknya kekebalan kelompok (herd imunity). Selain itu, vaksinasi Covid-19 bertujuan untuk melindungi dan memperkuat sistem kesehatan secara menyeluruh, juga menjaga produktivitas dan mengurangi dampak sosial dan ekonomi masyarakat.

Kementerian Kesehatan bersama beberapa organisasi (II AGI, UNICEF dan WHO) melakukan survei daring pada 19-30 September 2020 untuk mengetahui penerimaan publik terhadap vaksin COVID-19. Survei tersebut melibatkan lebih dari 115.000 responsden dari 34 provinsi di Indonesia. Berdasarkan survei tersebut, diketahui bahwa 658 responsden bersedia menerima vaksin COVID-19 jika disediakan Pemerintah, sedangkan 8\% di antaranya menolak. 274 sisanya menyatakan ragu dengan rencana pemerintah untuk mendistribusikan vaksin COVID-19.

Berdasarkan data responden yang dilakukan Kementerian Kesehatan bersama Indonesian Technical Advisory Group on Immunization (ITAGI) yang dirilis pada Oktober 2020, menunjukan bahwa masih ada sekitar 7,6 persen masyarakat yang menolak untuk divaksinasi dan 26,6 persen masyarakat 
belum memutuskan dan masih kebingungan (Sukmasih 2020).

Tidak semua golongan masyarakat langsung dapat diberikan vaksinasi hal ini berdasarkan Surat Edaran Nomor HK.02.02/I/368/2021 tentang Pelaksanaan Vaksinasi Covid-19 pada Kelompok Sasaran Lansia, Komorbid, dan Penyintas Covid-19 yang dikeluarkan oleh Direktorat Jenderal Pencegahan dan Pengendalian Penyakit Kemenkes. Diabetes dan penyakit kardiovaskular merupakan penyakit komorbid yang banyak diderita oleh masyarakat Indonesia dimana merupakan penyakit gangguan metabolic yang dikarakterisasi oleh keadaan hiperglikemia. Pasien Diabetes dapat divaksinasi sepanjang belum ada komplikasi akut (Kemenkes, 2021).

Berdasarkan hasil survey di dusun Tempit Desa Bajur Lombok barat, masyarakat sebagian besar (60\%) belum memahami apa itu vaksin Covid-19, keamanan \& kehalalan dari vaksin, manfaat dan efek samping dari vaksin yang mungkin muncul sehingga banyak masyarakat memiliki rasa takut untuk melakukan vaksinasi bahkan tidak mau untuk melakukan vaksinasi. Dengan demikian perlunya dilakukan atau diberikan edukasi kepada masyarakat tentang program vaksinasi, seperti yang kita ketahui, saat ini kita berada dalam masa pandemi dimana diperlukan adanya herd imunity untuk segera mengakhirinya, salah satu cara yang paling efektif adalah dengan vaksinasi dan tetap menjalankan protocol kesehatan. Maka pada kesempatan kali ini kami mengajak masyarakat Desa Bajur Dusun Tempit untuk memahami apa itu vaksin, bagaimana cara kerjanya, apa saja manfaat dan apa efek samping yang mungkin muncul pasca vaksinasi.

\section{MASALAH}

Alasan Saya memilih tempat pendidikan kesehatan tentang edukasi: peningkatan pengetahuan masyarakat tentang vaksinasi Covid-19 di dusun Tempit Desa Bajur Lombok Barat" karena masyarakatsebagian besar $(60 \%)$ belum memahami apa itu vaksin Covid-19, keamanan \& kehalalan dari vaksin, manfaat dan efek samping dari vaksin yang mungkin muncul sehingga banyak masyarakat memiliki rasa takut untuk melakukan vaksinasi bahkan tidak mau untuk melakukan vaksinasi. Dengan demikian perlunya dilakukan atau diberikan edukasi kepada masyarakat tentang program vaksinasi, seperti yang kita ketahui, saat ini kita berada dalam masa pandemi dimana diperlukan adanya herd imunity untuk segera mengakhirinya, salah satu cara yang paling efektif adalah dengan vaksinasi dan tetap menjalankan protokol kesehatan. Denah Lokasi:

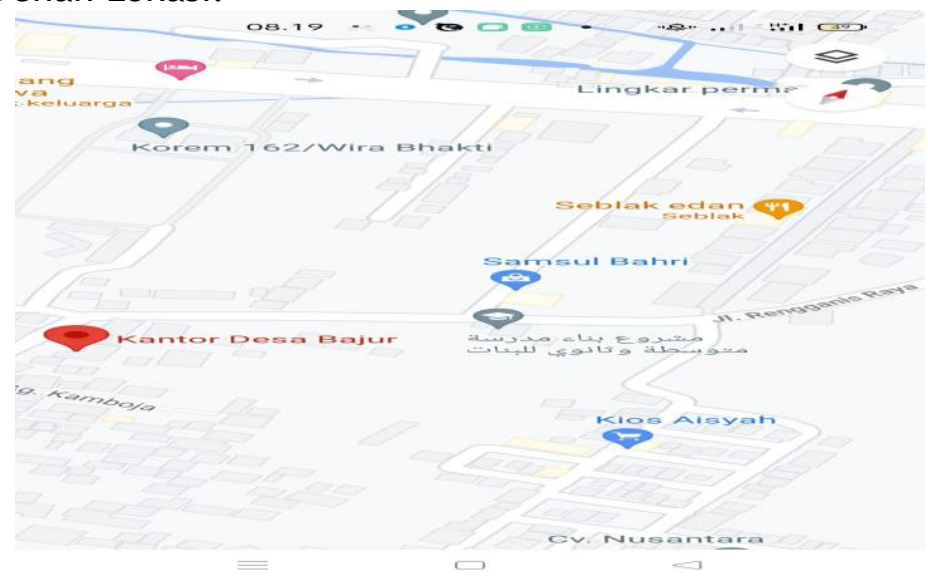

Gambar Peta Lokasi Kegiatan 


\section{METODE}

\section{a. Tujuan Persiapan}

Tahap persiapan dari kegiatan adalah pembuatan pre planning, persiapan materi yang akan disampaikan berupa power point dan leaflet, tempat dan alat pyoyektor LCD disiapkan di kediaman kepala Dusun Tempit Desa Bajur Lombok Barat". Pembuatan power point dan leaflet dimulai pada hari senin 24 Mei 2021. Pada tanggal 26 Mei 2021 dilakukan pengecekan untuk persiapan pelaksanaan pendidikan kesehatan supaya kegiatan dapat terlaksana lebihmaksimal

b. Tahap pelaksanaan

Pelaksanaan kegiatan ini terlebih dahulu dilakukan pemberitahuan kepada kepala dusun tempit Desa Bajur Lombok Barat bahwa akan dilakukan pendidikan kesehatan pada masyarakat tentang peningkatan pengetahuan masyarakat tentang vaksinasi Covid-19.

\section{c. Evaluasi}

\section{i. Struktur}

Peserta hadir sebanyak 33 peserta. Setting tempat sudah sesuai dengan rencana yang sudah direncanakan dan perlengkapan yang dilakukan untuk dilakukan pendidikan kesehatan sudah tersedia dan sudah digunakan sebagaimana mestinya. Penggunaan bahasa yang digunakan sudah komunikatif dalam penyampaiannya, masyarakat dusun tempit dapat mengetahui dan memahami materi yang sudah disampaikan tim pengabdian masyarakat mencapai $90 \%$ dan dapat memfasilitasi audiensi selama berjalannya kegiatan pendidikan kesehatan dan kegiatan Tanya jawab dengan peserta

\section{ii. Proses}

Pelaksanaan kegiatan pada hari kamis tanggal 27 Mei 2021 pukul 09.00 s/d 11.00 WITA. Sesuai dengan jadwal yang sudah direncanakan

\section{HASIL DAN PEMBAHASAN}

Pelaksanaan kegiatan pendidikan kesehatan ini dilaksanakan pada tanggal 27 Mei 2021di Dusun Tempit Desa Bajur Lombok Barat”. Pelaksanaan edukasi ditujukan pada semua masyarakat dusun tempit desa bajur Lombok barat dengan usia di atas 18 tahun. Media dan alat yang disediakan berupa LCD, materi power point dan leaflet. Metode yang digunakan adalah ceramah dan Tanya jawab. Dalam pelaksanaan kegiatan semua peserta tampak antusias untuk mengikuti kegiatan pendidikan kesehatan yang diberikan karena peserta menerangkan belum mendapatkan pendidikan kesehatan tentang vaksinasi Covid-19 dari desa setempat. Berikut gambar pelaksanaan kegiatan: 

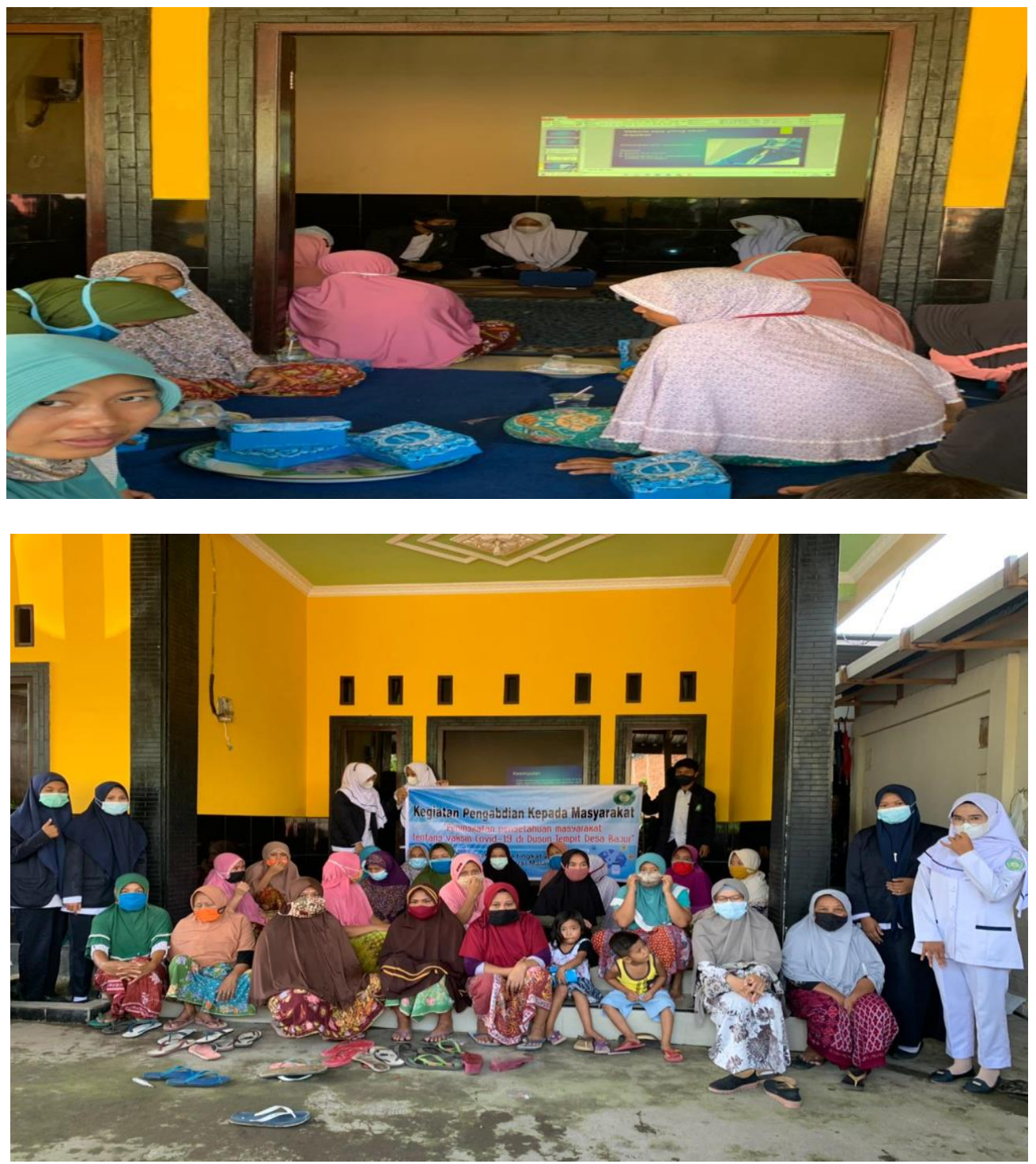

Gambar Pelaksanaan Kegiatan

\section{KESIMPULAN}

Berdasarkan pelaksanaan kegiatan edukasi yang dilakukan dapat disimpulkan bahwa setelah diberikan pendidikan kesehatan semua peserta tampak antusias untuk mengikuti kegiatan pendidikan kesehatan tentang "peningkatan pengetahuan masyarakat tentang vaksinasi Covid-19 di dusun tempit Desa Bajur Lombok Barat. Dimana pendidikan kesehatan ini bertujuan meningkatakan pengetahuan masyarakat tentang pentingnya mengikuti program pemerintah untuk melakukan vaksin Covid-19untuk menurunkan angka kesakitan dan kematian dan mendorong terbentuknya kekebalan kelompok (herd imunity) dalam masyarakat. 


\section{DAFTAR PUSTAKA}

Izazi, Farizah, dan Astrid Kusuma. (2020). “Hasil Responden Pengetahuan Masyarakat Terhadap Cara Pengolahan Temulawak (Curcuma Xanthorrhiza) dan Kencur (Kaemferia galanga) Sebagai Peningkatan Imunitas Selama COVID-19 dengan Menggunakan Kedekatan Konsep Program Leximancer." Journal of Pharmacy and Science 5(2):93-97.

Kemenkes RI, (2020). Pedoman Pencegahan dan Pengendalian Coronavirus Diseases).https://www.kemkes.go.id/resources/download/infoterkin i/COVID-19\%20dokumen\%20resmi/REV-04_Pedoman_P2_COVID19_\%2027\%20Maret2020_Tanpa\%20TTD.pdf.pdf

Kemenkes. (2021). Surat Edaran Nomor HK.02.02/I/368/2021, tanggal 11 Februari 2021, tentang Pelaksanaan Vaksinasi Covid-19 pada Kelompok Sasaran Lansia, Komorbid dan Penyintas Covid-19.

Kemenkes. (2021). Covid-19 dan Psikososial Masyarakat di Masa Pandemi.

Makmun. Armanto, dan Siti Fadhilah Hazhiyah. (2020). "Tinjaun Terkait Pengembangan Vaksin Covid-19." Molucca Medica 52-59. doi: 10.30598/molmed. 2020.

Mukti, A. W. (2019). Effectof Atorvastatin Treatmenton Vascular Aterogenic Factors(Lipid Profiles and VCAM 1) in Patient Diabetes with Dyslipidemia. Indonesian Journal of Pharmacy,30(2), 128-132.

Mukti, A. W. (2020). Pengaruh Kepatuhan Mengikuti Program Pengelolaan Penyakit Kronis (PROLANIS) Terhadap Kadar HbA1C pada Pasien Diabetes Mellitus Dengan Dislipidemia. Jurnal Medika Hutama, 1(02).

Mukti, A. W. (2020). Hubungan Pengetahuan terhadap Perilaku Penggunaan Suplemen Kesehatan Warga Kebonsari Surabaya di Masa Pandemi Covid-19. FARMASIS: Jurnal Sains Farmasi, 1(1), 20-25.

Sukmasih. (2020). Issues, Conflict and Public Opinion. Penerbit Lutfi Gilang.

Supardi, Sudibyo, Ondri Dwi Sampurno, dan Mulyono Notosiswoyo (2004). "Pengaruh penyuluhan obat terhadap peningkatan perilaku pengobatan sendiri yang sesuai dengan aturan." Indonesian Bulletin of Health Research32(4):65362.

Zainaro, M. A., Andoko, A., \& Rahmawati, R. P. (2021). Hubungan Pengetahuan dan Sikap Terhadap Kejadian Covid-19 pada Masyarakat di Kelurahan Mulyojati Kota Metro. Malahayati Nursing Journal, 3(4), 517-528. 